\title{
The Absolute of Advaita and the Spirit of Hegel: Situating Vedānta on the Horizons of British Idealisms
}

\author{
Ankur Barua ${ }^{1}$ (D)
}

Received: 27 July 2016/Accepted: 6 October 2016/Published online: 26 October 2016

(C) The Author(s) 2016. This article is published with open access at Springerlink.com

\begin{abstract}
Purpose A significant volume of philosophical literature produced by Indian academic philosophers in the first half of the twentieth century can be placed under the rubric of 'Śamkara and X', where X is Hegel, or a German or a British philosopher who had commented on, elaborated or critiqued the Hegelian system. We will explore in this essay the philosophical significance of Hegel-influenced systems as an intellectual conduit for these Indo-European conceptual encounters, and highlight how for some Indian philosophers the British variations on Hegelian systems were both a point of entry into debates over 'idealism' and 'realism' in contemporary European philosophy and an occasion for defending Advaita against the charge of propounding a doctrine of world illusionism.

Methodology Our study of the philosophical enquiries of A.C. Mukerji, P.T. Raju, and S.N.L. Shrivastava indicates that they developed distinctive styles of engaging with Hegelian idealisms as they reconfigured certain aspects of the classical Advaita of Śamkara through contemporary vocabulary.

Result and Conclusion These appropriations of Hegelian idioms can be placed under three overlapping styles: (a) Mukerji was partly involved in locating Advaita in an intermediate conceptual space between, on the one hand, Kantian agnosticism and, on the other hand, Hegelian absolutism; (b) Raju and Shrivastava presented Advaitic thought as the fulfilment of certain insights of Hegel and F.H. Bradley; and (c) the interrogations of Hegel's 'idealism' provided several Indian academic philosophers with a hermeneutic opportunity to revisit the vexed question of whether the 'idealism' of Śamkara reduces the phenomenal world, structured by $m \bar{a} y \bar{a}$, to a bundle of ideas.
\end{abstract}

Keywords Advaita Vedanta · A.C. Mukerji · P.T. Raju - S.N.L. Shrivastava • British Idealism · E. Caird · T.H. Green · German Idealism

Ankur Barua

ab309@cam.ac.uk

1 Faculty of Divinity, University of Cambridge, Cambridge, UK 
The theme of the emergence of certain forms of Hinduisms through various types of east-west dialogical interactions has been extensively studied in recent decades. From around 1900 onwards, some Hindu thinkers began to assimilate and critically interrogate a diverse range of European 'imaginations' of India, such as Christian missionary critiques of Hindu socio-religious universes, Orientalist projections of golden Vedic antiquities and enquiries into Indo-European linguistic morphologies, and utilitarian denunciations of the 'primitivism' of Hindu cultural systems. A topic that has been relatively underexplored in these intellectual transmissions and exchanges is the engagement of a range of Indian academic philosophers in the first half of the last century with a variety of Hegel-inspired philosophical systems. A significant volume of philosophical literature from this period can be placed under the rubric of 'Śamkara and $X$ ', where $X$ is Hegel, or a German or a British philosopher who had commented on, elaborated or critiqued the Hegelian system. We will explore in this essay the philosophical significance of Hegel-influenced systems as an intellectual conduit for these Indo-European conceptual encounters, and highlight how for some Indian philosophers the British variations on Hegelian systems were both a point of entry into debates over 'idealism' and 'realism' in contemporary European philosophy and an occasion for defending Advaita against the charge of propounding a doctrine of world illusionism.

The reception in Indian academic philosophical milieus of Hegelian thought, often mediated through British philosophers such as T.H. Green (1836-1882), E. Caird (1835-1908), and F.H. Bradley (1846-1924), was not uniform. While H. Haldar (University of Calcutta) was primarily a Hegelian thinker, who only occasionally employed Vedantic terminology to elucidate certain aspects of Hegel's system, A.C. Mukerji (University of Allahabad), P.T. Raju (Andhra University and the University of Rajasthan), S.N.L. Shrivastava (Vikrama University, Ujjain), and others directly drew from the perspectives of Advaita to critique specific themes in Hegelian thought. For Mukerji, Raju, Shrivastava, and others, Hegelian idealisms provided the common conceptual currency with which they could critically intervene in European philosophical disputes and also present Advaita Vedānta to European audiences. Consequently, the term 'Absolute' routinely appears in their texts, and, in fact, as S. Deshpande has noted, 'the singular question that occupied these philosophers in the early part of the twentieth century was as follows: "What is the nature of the Absolute?"' (Deshpande 2015: 19). As we will see, Mukerji, Raju, and Shrivastava developed distinctive styles of engaging with Hegelian idealisms as they reconfigured certain aspects of the classical Advaita of Śamkara through contemporary vocabulary. These appropriations of Hegelian idioms can be placed under three overlapping styles: (a) Mukerji was partly involved in locating Advaita in an intermediate conceptual space between, on the one hand, Kantian agnosticism and, on the other hand, Hegelian absolutism; (b) Raju and Shrivastava presented Advaitic thought as the fulfilment of certain insights of Hegel and Bradley; and (c) the interrogations of Hegel's 'idealism' provided several Indian academic philosophers with a hermeneutic opportunity to revisit the vexed question of whether the 'idealism' of Śamkara reduces the phenomenal world, structured by $m \bar{a} y \bar{a}$, to a bundle of ideas. Our exploration of three central texts, Mukerji's The Nature of Self (1943), Raju's Thought and reality: Hegelianism and Advaita (1937), 
and Shrivastava's Śamkara and Bradley: A Comparative and Critical Study (1968), will indicate that these philosophical currents formed a dense network stretched across three vertices: Hegel himself; the receptions and the reconfigurations of Hegel in a wide range of British idealists, from Green to Caird to Bradley; and the Indian philosophical interrogations, from the perspectives of modernized Advaita, of both Hegel himself and the British idealists who incorporated aspects of Hegelianism into their own metaphysical systems. While 'British Idealism', which emerged from around 1870, was not a singular movement but a group of somewhat divergent philosophical standpoints, D. Boucher and A. Vincent highlight a few shared themes. First, according to British idealism, there are no isolated entities or processes, and everything has to be understood in terms of their relationships within an internally differentiated whole. Second, the world is dependent on mind, not in the sense that it owes its very existence to mind but that it derives its intelligibility from mind. The claim is not that, for instance, a table ceases to exist once it is taken away from an observer, but that carpenters, scientists, and artists could see three different types of tables, where these differences are dependent on mind (Boucher and Vincent 2012: 39). These themes were critically received by the British idealists from the philosophical projects of German idealists who sought to respond to the critical idealism of Kant, variously by searching for an unconditional first principle of knowledge (Fichte), a philosophy of identity (Schelling), the absolute knowing which overcomes all subject-object dualisms (Hegel), and so on (Dudley 2007). Mukerji, Raju, Shrivastava, and others, as we will see, critically appropriated specific aspects of the 'holism' of the Hegelian Absolute, and also the post-Kantian critique of Berkeleyean idealism, as they reformulated, for the purpose of their philosophical conversations with Hegelianisms, some of the metaphysical themes of Advaita Vedānta. The Absolute of Advaita, it turns out, is not to be understood as the 'subjective idealism' of Berkeley, but not quite as the 'absolute idealism' of Hegel either, though it is conceptually much nearer the latter standpoint than the former.

\section{Advaita Between Kant and Hegel}

Mukerji's The Nature of Self (henceforth, NS) is a careful and systematic exploration of certain philosophical positions in British idealisms regarding the self. He sketches three broad patterns of British philosophical responses to Kant. First, though Kant had critiqued the basic assumption of Hume's empiricism, namely, that the epistemic subject first begins with a bundle of atomic sensations and then proceeds to unite them through psychological bonds of association, his transcendental idealism has not been properly appreciated in some strands of British philosophy. Various forms of contemporary realisms, pragmatisms, and pluralisms operate with the pre-Kantian view that things are self-existing distinct entities before they enter into relations with one another. While some philosophers have indeed rejected the basic thesis of British empiricists such as Locke, Berkeley, and Hume-that the world is composed of self-existing, metaphysically independent and isolated entities which are only subsequently related to one another through 
conceptual abstractions - they have arrived at two somewhat divergent conclusions. First, some have moved towards Kant's agnosticism regarding the noumenon, and view the self as a bare that which remains completely unknowable. Second, others have elaborated Hegelian understandings of self-consciousness in terms of the self's developing awareness of itself through its awareness of objects, thereby reducing the self, according to Mukerji, to the status of an empirical entity. At this critical stage of the argument, Mukerji presents Śamkara's Advaita as a via media between these extremes in post-Kantian idealisms: on the other hand, the Absolute of Advaita (unlike the Kantian noumenon) is not utterly unknowable, for it is the selfrevealing consciousness which is the ever-present background illumination in all empirical knowledge, but, on the other hand, the Absolute of Advaita (unlike the Hegelian organic whole) is a pure undifferentiated unity and not the selfconsciousness structured by identity-in-difference of various British 'neo-Hegelian' idealisms. Mukerji's philosophical project, then, is not a nativist-styled return to Śamkara, but a creative intervention, from modernized Advaita perspectives, in post-Kantian metaphysical and epistemological debates about the nature of consciousness.

Mukerji begins by noting that the problem of the self is structured by a paradox: while every object implies a self that knows that object, this statement would suggest that there must also be a knower that knows the self (NS, 5). According to Mukerji, the question 'Who knows the knower?' signals a key debate across a range of contemporary British philosophers, who have, however, missed the point that the self is not only not an empirical object but also not a psychological subject. The notion that the self is essentially unknowable through empirical modes is found in various Upanișadic texts and subsequently in Samkara's understanding of the self. This doctrine has recently emerged in Kant's critical philosophy, where his critique of rational psychology for mistakenly extending the categories of thought to the transcendental ego is, according to Mukerji, reminiscent of the teachings of the Upaniṣads and Śamkara (NS, 24). Philosophers should avoid the confusion, labelled transcendental illusion by Kant and adhyāsa by Śamkara, of mistaking the pure ego with the objects of knowledge, for by overlooking the distinctions between the innermost subject and the empirical objects, there arises various mistaken theories such as epiphenomenalism and behaviourism (NS, 26).

Mukerji notes that two methods have been developed in recent British philosophy to resolve the egocentric paradox, namely, the experimental or inductive method, and the logical or transcendental method. The former is employed by psychologists such as J.B. Watson who seek to replace the vocabulary of consciousness with that of physiological processes. These attempts to remove the pure ego from an analysis of knowledge commit the fallacy of the 'decentralization of the self', which involves the misidentification of the real self with objective entities and states, which are in fact spurious egos. The fundamental problem that theories produced through this method have to face is that of an infinite regress: when a subject $S$ knows objects $\mathrm{O}$, each with specific properties, $\mathrm{S}$ itself cannot have these properties, for it would then become another object and would require $S^{*}$ by which it can be known (NS, 9-12). The basic error lies in the forgetfulness on part of the subject $S$ that $\mathrm{S}$ itself stands in a unique relation to the objects which cannot be excavated 
through an empirical analysis. For instance, when knowledge is reduced to a set of physiological and mental processes, it is forgotten that these processes are intelligible to $S$ only if the transcendental conditions of S's relation to them are not reducible to the relations between objects. One such transcendental condition for the conceivability of an object is that it is a self-consistent unity. Therefore, when $\mathrm{S}$ knows an object $\mathrm{A}$ and another object $\mathrm{B}$, the interobjective relations that obtain between A and B are completely distinct from the 'relation' of A and B individually with $\mathrm{S}$. The inductive method is not capable of uncovering these transcendental conditions of possible experience, because it is precisely these conditions, discoverable only through a reflective analysis of the nature of knowledge, that make the application of the method possible (NS, 15). On the other hand, the Kantian transcendental method correctly emphasizes that the 'logical implicates of experience' such as space, time, and causality cannot be known in the same way that specific empirical objects are known. The post-Kantian developers of this method argue that all objective entities, such as tables and trees, as well as the universal conditions of objects of experience, such as space and time, exist for the self which is in this sense 'the centre of the universe'. Mukerji notes that this method has 'staunch advocates not only in England where Hegelianism has come to establish itself as a permanent philosophical tendency, but it is accepted as final also by many accomplished thinkers of contemporary Italy and India ...' (NS, 17).

However, while British idealists such as Green and Caird have correctly accepted the transcendental approach to the ego, they are engaged in a 'logical see-saw' in which they have alternately emphasized one of the following points, both of which they have inherited from Kant: the self as the transcendental presupposition of empirical objects, and the self as unknowable. Green has highlighted the distinction between the pure ego and empirical objects and denied that the pure ego is knowable, while Caird has emphasized the knowability of the pure ego and almost removed its distinction from empirical objects (NS, 70). Mukerji has in mind statements of Green such as the following: 'That there is such a consciousness is implied in the existence of the world; but what it is we only know through its so far acting in us as to enable us, however partially and interruptedly, to have knowledge of a world or an intelligent experience' (NS, 74). According to Mukerji's reading, if Green veers, in this manner, towards a deep agnosticism about the self, Caird, on the other hand, mistakenly introduces empirical categories into the self. Caird argues that the self constitutes itself by opposing itself as its object, and by overcoming this very opposition, such that the self is a concrete unity of identity-in-difference. Unity and difference should be seen as inseparably connected in self-consciousness, through which the self knows itself and all its objects: 'the self exists as one self only as it opposes itself, as object, to itself, as subject, and immediately denies and transcends that opposition. Only because it is such a concrete unity, which has in itself a resolved contradiction, can the intelligence cope with all the manifoldness and division of the mighty universe ...' (Caird 2002 [1883]: 116). Responding to Caird's notion of the self as an 'organic unity', Mukerji allows that unity-indifference may be the most universal form to which every object of experience conforms; however, this universality does not show that the true subject itself is a unity-in-difference, for the subject is the logical presupposition of all categories, 
including the category of 'unity' which cannot be applied to the subject (NS, 1819). Therefore, he criticizes Caird for viewing the self as the correlative of the notself, arguing that on this account the self is another empirical object, and not the real self which is the presupposition of all objects (NS, 21). Mukerji's Kantian point is that since a 'category' is a principle of interpretation that is employed to objects of experience, the self cannot itself be a category, even the highest category, since every category implies an ultimate unity (NS, 98-99).

The point of this subtle discussion of the complexities of British idealisms emerges gradually: Mukerji seeks to situate Advaita in a conceptual space somewhere between the systems of Caird and Green. On the one hand, because Caird views self-consciousness as a unity that is mediated through its consciousness of objects, he effectively views the self as an empirical object (NS, 90). Noting Caird's view that only with the 'return' of the self to itself or the reduplication of the self in the judgment 'I am I', that the 'ego, strictly speaking, comes into existence' (Caird 1889: 403), Mukerji argues that this developmental account of the self, which progresses from consciousness to self-consciousness, presupposes the categories of space and time which are the transcendental conditions of any entity that undergoes a processive change. Therefore, Caird's developmental self cannot be the true subject, which is the very source of the categories and cannot be an object which is comprehended by the categories (NS, 88). Mukerji is more sympathetic to Green's engagements with Kant, noting that both Green and Śamkara view consciousness as a reality which has none of the characteristics that belong to knowable objects (visaya) (NS, 144). He argues that Śamkara's argument that every perceptual judgement involves two principles, namely an unchanging spiritual unity (cit) and a stream of transient cognitions (vrtti-pravāha) of the mind (antahkaraṇa), is analogous to Kant's distinction, later elaborated by Green, between the transcendental unity of apperception and the successive states of knowledge. Mukerji comments: 'And what must be eminently interesting for a modern philosopher is the similarity of Green's analysis with that of Sankara' (NS, 175). However, while both Samkara and Green highlight the point that the self is the logical presupposition of experience and hence cannot be placed under the categories, there is a fundamental divergence in their conceptual systems regarding the question of knowledge of the self. While Green, following Kant, exhibits a 'drift to agnosticism' and regards the noumenal self as completely unknowable, the Advaita standpoint is that selfrevealing consciousness (svayamprakāśa), which is both eminently real and yet not an object, is present in all empirical consciousness (NS, 129-130). According to Mukerji, the basic error of Kant, and of Green in his Kantian moments, is to view reality, on the one hand, and the phenomenal world, on the other hand, as congruent, and to conclude from this equivalence that the noumenal self, because it is unknowable, is merely an imaginary point. According to Advaita, however, reality is more expansive than Kant's phenomenal world, so that the pure consciousness of Advaita, though indescribable, is not a completely inconceivable $\mathrm{x}$, but rather 'the indispensable support of all objects and of all relations among the objects' (NS, 342). Therefore, the Advaita of Śamkara gives us, according to Mukerji, a conceptual pathway that avoids the errors of Caird and Green: on the one hand, the Absolute of Advaita cannot be characterized in terms of any empirical categories 
which are relational, but, on the other hand, it is not a Kantian thing-in-itself which is entirely unknown. Sankara avoids the 'opposite fallacies' of viewing the self as an empirical object (which, according to Mukerji, is effectively Caird's response to Kant) and as a pure nothing (which is the 'drift' of Green), for while Sankara emphasizes that the conditions under which objects are known cannot be applied to the knower, he also asserts that 'what is thus beyond the conditions of the knowable objects is our very self. The self in this sense is said to be beyond the known and above the unknown' (NS, 270). Thus, the Advaitic self is not unknown and unknowable in the same sense as the Kantian noumenon. The self is said to be selfrevealing, for everyday experience presupposes a 'self-experience' which is the condition of empirical knowledge. However, this 'self-experience' is not the experience of the self as an object, rather it is a non-objectifying immediate experience which, in an Advaita analogy, is like light which does not stand in need of an external light for is own illumination. The 'entire tenor and drift' of the Upanișads is that Brahman, far from being a transcendental principle that is unknown or otherwise accessible only to mystics, is ever present in the 'selfexperience' of everyday life (NS, 378). The self of Advaita should not be viewed as a transcendental Principle, along the lines of a Platonic archetype, but rather as the immanent presupposition of all experience. Therefore, the unity of consciousness, for Śamkara, is not an abstract unknown but is 'real in a certain sense' (NS, 341).

The crucial phrase here is 'in a certain sense', for if Mukerji seeks to situate Śamkara between Green and Caird, this is also because he presents Advaita as an intermediate path through the systems of Kant and Hegel. While the Absolute of Advaita is the most foundational reality, and not a mere conceptual limitation such as the Kantian noumenon, it is not a relational whole such as the Hegelian Absolute. On the one hand, Mukerji draws extensive parallels between Śamkara's views on the self and Kantian statements about the noumenal self. Mukerji argues that Kant's affirmation of the transcendental unity of apperception can be put in Śamkara's terms as follows: the conscious self is the presupposition (grāhik $\bar{a})$ of the fleeting events of knowledge (NS, 218). Pointing out that Samkara restricted categories such as generic unity, specific difference, action, quality, and relation to empirical objects, Mukerji comments that it may be 'remarked without running the risk of being accused of overzeal that Sankara was essentially expressing the same truth that inspired Kant's doctrine at a later age' (NS, 157). The most significant of Śamkara's conclusions, namely, that the 'foundational character' of unvarying consciousness is the presupposition of our experience of objects is also a theme that is shared by the contemporary 'idealistic school' which states that the self provides the a priori conditions of the determination of the objects of experience. Mukerji states that the 'development of post-Kantian idealism bears eloquent testimony to the vitality of the Advaita position and the former may in this respect be regarded as an elaborate exposition and ramification of the latter' (NS, 119). However, as we have noted, Mukerji's basic objection to the Kantian system is the postulation of the noumenon, and he argues that this thing-in-itself has been 'rightly rejected' by idealists such as Fichte and Bradley. While Kant concludes with an agnosticism about the self, for Śamkara the Absolute is the pre-established ground (svayamsiddha) of all relational thought (NS, 308-309). Samkara does claim that the Absolute 
is beyond all speech and thought, but he also affirms that Brahman is not a mere nothing (abhāva) (Brahma-sūtra-bhāsya III.2.22; NS, 311). On the other hand, Mukerji's rejection of the Kantian noumenon does not amount to a full-fledged acceptance of the Hegelian system. He argues that while the Advaita tradition agrees with Hegel that distinctions presuppose an underlying unity, it rejects Hegel's understanding of the infinite. Whereas for Hegel, true infinity is not opposed to its other but includes it, so that the highest category of reality is that of unity-in-difference, Advaita responds that unity-in-difference itself is a category that applies to objects but not to the Absolute which is the very presupposition of these objects (NS, 350). Mukerji therefore offers a critique of post-Kantian idealisms for transforming Kant's transcendental subject into a universal Spirit by viewing the Kantian logical unity as a determinate object, which is a unity manifested in differences. The error lies, according to Mukerji, in viewing the noumenal subject not simply as a limiting concept but as a positive, though transphenomenal, thing or object of thought (NS, 104-105). These post-Kantian idealists view subject and object as correlative terms, so that an object of thought should be properly understood in terms neither of identity nor of difference, but of identity-indifference, which is a unity of differents. At the same time, the subject is regarded as a higher-order reality, because this correlativity of subject and object is a correlativity for the subject. This line of argument 'gradually leads to the conclusion that the world is the self-manifestation of a spiritual principle which is a universal that differentiates itself and yet is one with itself in its particularity' (Mukerji 1936: 448). Mukerji rejects the basic premise of this argument, namely, that subject and object are correlative, noting that the true subject cannot be placed under any empirical categories that apply to objects, since it is the logical presupposition of empirical experience. However, because of the influence of Hegelianism, thinkers from different countries mistakenly continue to reject the notion of the self as pure consciousness. They wrongly assume that the self comes into existence through the I-consciousness which contrasts itself with consciousness of objects; rather, it is because the self exists as a synthetic principle that the I-consciousness can emerge with pure consciousness as its transcendental presupposition (NS, 333). Therefore, while there is a 'strong tendency' on the part of some Indian philosophers such as Haldar to minimize the distinctions between Advaita and Hegelian absolutism, there is in fact a 'deep chasm' between the two: Hegelian idealism is based on the mediated unity of the concrete universal, whereas Advaita is grounded in a pure immediacy which is not an organic unity of distinct individuals (NS, 277-79).

\section{Advaita as the Fulfilment of Hegel and Bradley}

Mukerji's basic theme that Advaita rejects the Hegelian Absolute as a spiritual unity-in-difference which expresses itself in parts also appears in Raju and Shrivastava, who expressly present the Absolute of Advaita as the most consistent resolution of the conceptual puzzles involved in 'relating' the one and the many. By drawing on various classical Advaitins such as Śrī Harșa, they argue that the Hegelian Absolute, which they read as a relational whole of the eternal and the 
temporal, is logically contradictory - the Advaita of Śamkara, in contrast, cannot be placed under any categories of thought, including identity-in-difference which is a relational category. They highlight the point that Bradley places his Absolute above the operations of categorical thought: according to Bradley, relational experience is riddled with inner contradictions which can be resolved only in the 'immediate experience' of the supra-rational Absolute. Bradley's Appearance and Reality contains various turns of phrase which, for his Indian Vedantic interlocutors, are reminiscent of the Advaita theme of $m \bar{a} y \bar{a}$ as the principle of the phenomenal world's inexplicability, for instance, Bradley's statement that '[t]he fact of appearance, and of the diversity of its particular spheres, we found was inexplicable. Why there are appearances, and why appearances of such various kinds, are questions not to be answered' (Bradley 1893: 511). However, while Bradley's Absolute approximates to the Absolute of Advaita in some respects, his Vedantic readers ultimately reject his system on the grounds that he retains the Hegelian error of regarding the Absolute as an organic whole of interrelated elements.

Raju argues in his Thought and reality: Hegelianism and Advaita (henceforth, TR) that while Hegelians struggle to explain the relation between the infinite and the finite, the proper response to this problem is that, strictly speaking, no such relation can be logically elaborated. If this relation is viewed as an identity-in-difference, this category is simply a restatement of the problem in different terms, for one would have to explain the relation itself between identity and difference (TR, 44). He discusses various Hegelian attempts to relate individuals to the organic whole of the Absolute and argues that they are unsuccessful in logically spelling out the relation between distinct substantial selves and the eternally perfect Absolute (TR, 58). The 'relation' of the finite and the infinite, the 'crux of all monism', has been most successfully addressed by Śamkara: while all finite selves are, sub specie aeternitatis, identical with Brahman, they are, sub specie temporis, characterized by multiplicity. If one self is liberated, $m \bar{a} y \bar{a}$, which structures the phenomenal world, disappears only for it and not for others, so that in this sense each self has a distinct individuality. However, noumenally the self does not exist as a substantial identity, for it is one with Brahman, which is without a second. Therefore, we can move from Bradley to Śamkara with only a 'few steps': Bradley correctly notes that appearances, such as the finite self, are riddled with internal contradictions, and these must undergo a complete transmutation into the Absolute. However, Bradley continues to retain the appearances somehow in the Absolute, because he is not entirely willing to view the Absolute as totally beyond thought. Raju claims that ' $\mathrm{h}]$ ad Bradley given up his Hegelian bias, rejected the appearance as such as in no way forming part of reality, and thus saved the eternal perfection of the Absolute, he would have joined hands with Sankara' (TR, 61).

Raju's claim that Bradley was inconsistent in holding on to the appearances in the Absolute is a recurring theme in Shrivastava's Śamkara and Bradley: A Comparative and Critical Study (henceforth, SB), which both provides detailed analogues between Bradley's thought and the Advaita of Śmkara, and argues that the former remains contains some contradictions that can be resolved by the latter. On the one hand, Shrivastava argues that various aspects of Bradley's thought resonate with the basic themes of Śamkara's Advaita. For Bradley, relational modes 
of thinking, which apply to concepts such as space, time, and self, are riddled with contradictions, so that reason yields only appearances and not truth. The contradictions in the appearances which structure everyday life can be resolved only in the Absolute which, like the Absolute of Samkara, transcends all discursive reasoning. On the other hand, however, Śamkara and Bradley disagree over the nature of this supra-relational Absolute: for Samkara, the Absolute is indivisible, undifferentiated, and one, such that differences are superimposed on it only through ignorance (avidyā), whereas for Bradley the Absolute is a 'concrete individual' which is a unity of sameness and difference. Shrivastava argues that Bradley's position is similar to the bhedābheda Vedantic doctrine, according to which identity-in-difference is the proper characterization of the relation between the substantially real world and the Absolute, so that the critiques of Advaitins such as Śrī Harṣa against the bhedābheda also apply to Bradley's understanding of the Absolute (SB, 7). As the reference to bhedābheda suggests, Shrivastava's engagement with Bradley proceeds through a critical examination of Bradley's attempt to affirm, on the one hand, that every appearance is real, although to different degrees, and, on the other hand, that every appearance has to be 'transmuted', through mutual supplementation and rearrangement, into the Absolute (Bradley 1893: 489). Thus, Bradley argues: '[I]n the Absolute no appearance can be lost. Each one contributes and is essential to the unity of the whole ... Every element however subordinate, is preserved in that relative whole in which its character is taken up and merged' (Bradley 1893: 456-457). Therefore, while it is a half-truth that no individual appearance is the perfection of the Absolute, it is also a half-truth that ' $[\mathrm{t}]$ he Absolute is its appearances, it really is all and every one of them' (Bradley 1893: 431). Seeking to preserve the reality of the appearances in the Absolute, Bradley argues in this manner: 'The Absolute ... has no assets beyond appearance; and again, with appearances alone to its credit, the Absolute would be bankrupt' (Bradley 1893: 489). Shrivastava seizes on these statements and argues that Bradley's position involves the contradiction of stating that 'an appearance retains its individuality' in the Absolute and 'an appearance is transmuted' in the Absolute (SB, 85). When Bradley claims that '[e]verything in the Absolute is still that which it is for itself. Its private character remains, and is but neutralized by complement and addition' (Bradley 1893: 511), Shrivastava responds that a finite appearance cannot undergo such a transformation while simultaneously maintaining its specificity. However, Bradley's position can be rendered consistent through Śamkara's understanding of reality in terms of the supra-relational one which appears, through avidy $\bar{a}$, in the diversities of a phenomenal word (SB, 7). That is, while the inconsistences of Bradley's system are a result of his understanding of the Absolute as a harmonious blend of eternally existing appearances, for Śamkara it is illogical to speak in this manner of integrating the phenomenal world into the timeless Brahman (SB, 47). Bradley's view that the Real is qualified by diversity, when translated into Vedantic categories, approximates to the cosmological notion of saprapañca-brahmavāda, according to which a substantially real world (prapañca) is grounded in the ultimate reality, Brahman. If Bradley had simply asserted that the Absolute is an organic unity of diverse components or even that it is not an undifferentiated unity, this view, Shrivastava claims, would at least have 
been comprehensible; however, Bradley contradicts his own statement that the Absolute is utterly non-relational by speaking of the many as 'qualifying' the one (SB, 56). Echoing Raju's claim that we noted earlier, about Bradley 'joining hands' with Śamkara, Shrivastava too states: 'The super-relational Absolute cannot ... possess internal diversity or distinctions ... If only Bradley had realized what his own premises pushed to their logical conclusions lead to, he would have come to this very conclusion and joined hand with Śamkara' (SB, 246).

\section{Advaita as the Synthesis of 'Idealism' and 'Realism'}

The emergence of post-Hegelian debates over 'idealism' and 'realism' in British philosophical circles was roughly concurrent with British Orientalist representations of Advaita Vedānta as a system of world negation and cosmic illusionism. Therefore, the interrogation of the multiple significances of 'idealism' in British philosophical thought was also an occasion for reclaiming, or foregrounding, some of the empirically realist strands in Śamkara's Advaita. Figures such as Mukerji emphasized that the 'idealism' of Śamkara should not be confused, any more than the idealisms of Hegel, Bradley, and others, with a sort of Berkeleyanism that analyses the phenomenal world in terms of ideas. While the foundational nature of consciousness is often interpreted as a denial of the extra-mental reality of the world, Mukerji argues that it is important to clearly distinguish between this metaphysical idealism and the assertion of the logical priority of consciousness. The notion of consciousness as the logical presupposition of all experience is compatible with both metaphysical realism and metaphysical idealism: 'Even if it be granted that knowledge does not create but only reveals a pre-existent reality, yet it would remain unchallengeable that the external reality could not be revealed to us apart from consciousness which is the principle of revelation' (NS, 122). That is, even if we accept the metaphysically realist thesis that there is a mind-independent world, for an object to be known by a self, it must be apprehended by the self through the transcendental conditions of experience (NS, 8-9). Mukerji concedes that a metaphysical realist might argue that this epistemological priority of consciousness should not be conflated with its chronological priority, so that although consciousness is presupposed in every act of knowing, the emergence of consciousness has a developmental history. Mukerji notes, however, that this response ignores 'the plain fact that the quid anterior to consciousness has no meaning for us, and so cannot be appealed to in explanation of anything ...' That is, the non-conceptualized quid that materialist theories of consciousness appeal to is a quid that is intelligible only insofar as it is presented to a self. This is how he reads Śamkara's argument that while cognitions have specific temporal determinations, "that for which these temporal relations have a meaning cannot be itself in time; it is in this sense an eternal presence' (NS, 144-45). Mukerji, in fact, suggests that Śamkara was an empirical realist about the phenomenal world. The statement that all empirical reality is rooted in the Absolute does not imply that everyday objects are dissolved into the Absolute, or that human moral and religious aspirations are demoted to the status of mere illusions: 'To urge that my world would not exist if I had not existed 
is not to prove that the world I know is my ideas only' (NS, 323). We should therefore understand the difference between 'realism' and 'idealism' in this manner: while the realist accepts as unproblematic the 'fact' that we inhabit an external world, the idealist asks for an analysis of the conditions under which this 'fact' is established. Therefore, while the realist 'takes the facts "at their face-value", the idealist asks for the conditions involved in the factual nature of the so-called facts' (Mukerji 2011: 475). Provided the terms are understood in this manner, we can see that in his response to Hume Kant not only 'undermined the basis of realism' but also developed a form of idealism which is opposed to subjective idealism. Mukerji argues that a Kantian can agree with a realist that the world is not composed merely of bundles of fleeting ideas, even while pointing out to the realist that the nature which is the subject of scientific investigation is not given to us in any way other than through our scientific theories, and it is therefore not possible to check whether these theories correspond to an extra-theoretical nature. As N. Bhushan and J. Garfield point out, Mukerji's idealism is not subjectivist and it does not reject an extra-mental world; rather, 'Mukerji defends a robust realism about the natural world and an intersubjective account of the constitution of our ontology' (Bhushan and Garfield 2011: 461).

While Hiralal Haldar did not directly draw on Śamkara, his synthesis of idealism and realism resembles Mukerji's rejection of Berkeleyan subjectivism and the affirmation of the self's categorical presuppositions in empirical experience. Haldar describes his intellectual debt to Hegel in these terms: 'I have seen myself described as a Hegelian. The basis of my thought is undoubtedly Hegelian, but in the course of years ... I have been led to modify in many ways what I have learned from Hegel' (Haldar 1936: 316). Haldar argues that the subjective idealist conflates the subjective mental ideas with their objective referents in the external world whose existence is not dependent on the mind. However, while the error of Berkeleyean idealism is to minimize the opposition between subject and object, realism makes the opposite error of setting them apart completely. Both 'undifferentiated unity' and 'pure difference' are abstractions, and in the concrete world unity and difference are interrelated as aspects of the Absolute which does not obliterate the distinctions between self and not-self, but maintains and transcends them (Haldar 1936: 322-323). Haldar argues that mind and matter should not be seen as mutually opposed for they are correlated aspects of the universal Spirit. Therefore, idealism, properly understood, does not deny the reality of the external world, but goes farther than realism by 'maintaining that the world is indeed real ... but that in order to know that it is real it has got to have mind' (Haldar 1936: 323). This Hegelian thesis of the identity of thought and being can be understood, according to Haldar, as the logical culmination of Kant's critical philosophy. While Kant demonstrated in his transcendental deduction that our knowledge of the objective world and the synthetic unity of self-consciousness are relative to each other, Hegel developed this Kantian theme to the conclusion that there is a higher unity which both comprehends and transcends the self and the world, and makes possible their correlativity (Haldar 1896: 265). Thus, as T. Biswas (2015: 116) notes: 'Unlike realism, Haldar's Realistic-Idealism does not consider the division between mind 
and matter as Absolute, nor like subjective idealism does it reduce matter to mental states'.

\section{Advaita and the Project of Comparative Philosophy}

Mukerji, Raju, and Shrivastava, in their somewhat distinctive ways, intervened in post-Kantian debates, sometimes mediated by British philosophers, about the nature of the self and the Absolute. Their hermeneutic projects were also pioneering exercises in 'comparative philosophy', and they often reflected on the methodologies of their readings, from within the contexts of Advaita, of various British idealists. Raju notes that comparative philosophy has been criticized for focusing primarily on similarities and not engaging critically with differences across conceptual systems. For example, when Śamkara's Brahman is compared with Spinoza's eternal substance, it is forgotten that Samkara applies a dialectic in indicating the self-established Brahman and would have disagreed with Spinoza's attempt, through his geometrical method, to deduce the phenomenal world from the eternal. Therefore, Raju argues that comparisons should be attempted between entire systems of concepts with their detailed interrelations, and not between individual concepts (TR, 25). The emphasis on the methodical exploration of conceptual systems is reiterated by Shrivastava more specifically in the case of comparative studies of Śamkara and Bradley, which, he notes, 'have usually contented themselves with merely pointing out superficial similarities and have therefore failed to probe deeper into their fundamental differences; or else they have overemphasized differences and consequently failed to appreciate the underlying unity in the thinking ...' $(\mathrm{SB}, 5)$.

A cursory reading of Mukerji's Nature of Self would seem to suggest that he is engaged in merely cataloguing resemblances between European philosophical standpoints and Advaitic themes. For instance, Mukerji notes that Śamkara, in his commentary on the Praśnopanișad VI.2, had discussed four competing theories of consciousness and argues that 'almost every theory of consciousness that is still in the forefront of philosophical discussion today' can be placed under one of Śamkara's headings (NS, 117). Again, he argues that Śamkara's arguments against the Buddhist understanding of causality in terms of dependent arising 'embody essentially Green's criticism of Hume's attempt to combine the theory of flux with causal connection' (NS, 195). After quoting Green's remark, 'yet, just so far as they [Hume's impressions] are qualified by likeness or unlikeness to each other, they must be taken out of that succession by something which is not itself in it, but is individually present to every moment of it' (Nettleship 1888, vol. I: 176), Mukerji argues that this statement indicates that Śamkara had anticipated Green's critique of the Humean reduction in the self to bundles of perceptions (NS, 200). However, Mukerji highlights these parallels, in the course of offering detailed readings of the metaphysical and epistemological projects of certain post-Kantian idealisms, only to engage his British interlocutors in philosophical conversations whose themes are partly shaped by Advaitic vocabularies. He too criticizes attempts to compile lists of conceptual parallels across European and Indic systems, without highlighting their 
locations in distinctive philosophical contexts. While anyone with an 'unprejudiced insight into Indian philosophy' will know that the classical traditions possessed numerous dialectical weapons which are as effective in the dialectical engagements of contemporary philosophy as they were in ancient India, one should be aware that post-Kantian epistemology is structured by highly specific problems which were not the concerns of the ancient Indian thinkers. Therefore, if we wish to gain 'by thinking modern problems of European philosophy in Indian terms without misrepresentation of either and yet with a considerable clarification of both methods of thought, we must give up the practice of finding Kant and Hegel, for instance, in the Upanishads; these are misrepresentations which do not clarify but compound problems' (Mukerji 1928: 379). For instance, the Kantian distinction between precept and concept, or between sense and thought, emerges from within a European intellectual atmosphere and is not found, Mukerji argues, in classical Indian philosophical texts. Therefore, he criticizes attempts to align the Kantian view of sensations conforming to a priori structures with Upanisadic vocabularies by offering 'extremely far-fetched interpretations' of the terms manas and vijñana as perception and understanding, respectively (Mukerji 1928: 401-402). The 'most deep-lying contrast' between Vedantic thought and post-Kantian European philosophy is that while the supra-rational experience of unity with the cosmic consciousness is the very foundation of Vedantic metaphysics, the latter exalts reason as the ultimate court of appeal in epistemology (Mukerji 1928: 393). Whereas for Samkara intuitive experience is the ultimate criterion of truth, and reason is viewed as an auxiliary to the revelation of reality, Hegelians do not accept the possibility of such an experience and speak of the revelation of reality through the mediating activity of thought.

Therefore, the interrogation of a variety of Hegelianisms through the prisms of Advaita Vedanta was also a crucial moment in the constructions of Hindu thought as spiritual, intuitive, or experiential. Wilhelm Halbfass pointed out that various European figures, starting from the early nineteenth century down to Edmund Husserl in the last, associated 'philosophy' with 'pure theory', 'rejection of mythos' and 'autonomous thinking' which were believed to be distinctively Greek and lacking in the Indian and Oriental traditions (Halbfass 1990: 145-159). Opposing this exclusion of 'philosophy' from India, pivotal figures such as Swami Vivekananda and S. Radhakrishnan presented Indian 'philosophy' in oppositional terms to European 'philosophy', such that while the latter was merely rational, analytic and restricted to the empirical plane, the former was essentially spiritual, based on 'intuitive experience', and provided an overarching framework which synthesized the European manifold of 'economics', 'sociopolitical existence', and 'religion' (Halbfass 1990: 287-309). These 'synthetic' visions of modernized Advaita are deeply resonant with the metaphysical systems of the British idealists who, R. Sinnerbrink argues, 'shared a critical attitude towards reductive empiricism, a commitment to metaphysical holism and a valorization of moral freedom' (Sinnerbrink 2007: 33). British Idealism, which emerged in late Victorian England against the backdrop of various sociocultural upheavals that had followed rapid industrialization and expansion of global trade, was both a philosophical movement which opposed the strains of empiricism, naturalism, and utilitarianism in British 
thought, and a social reformist force which emphasized social justice and social responsibility in conditions of exploitation, poor working conditions, and widespread disease. Boucher and Vincent argue that 'British Idealism was a social philosophy that exuded optimism at a time of extreme social dislocation and pessimism. In summary, it acted as a profound interrogation, critique and metaphysical counterbalance to the individualism of the variants of an instinctive British utilitarianism and naturalistic evolutionism' (Boucher and Vincent 2012: 4).

Diverse aspects of these British Hegelian visions were appropriated, in the sociopolitical contexts of late colonial India, through the lenses of reconfigured versions of classical Advaita. While we cannot discuss the momentous question of what Hegel himself meant by the Spirit (Geist), Hegel's view that in the Absolute idea there is the reconciliation of subject and object has been understood in at least two ways. On one reading, Hegel is extending Kant's transcendental idealism by rejecting the thing-in-itself and emphasizing the social nature of the categories of thought. For Hegel, the world is the work of reason in the sense that the objects of experience are constituted through the categories of rational thought. However, on another reading, especially of late texts such as the Lectures on the Philosophy of Religion, Hegel is suggesting that the world is the product of divine reason, and human beings can understand this world because their reason is identical with divine reason (Norman 1976: 110-115). Of the philosophers we have discussed, Haldar occasionally tends towards the second reading of Hegel: he views Hegel's Absolute as an organic unity which is subject-object, where the subject is a community of selves and the objects are a system of interrelated things (Haldar 1917: 390-393). The Absolute is one not because it is beyond all differences but precisely because it is expressed in and through differences. Therefore, on the one hand, the Absolute does not dissolve into itself the plurality of the selves, and on the other hand, it does not stand beyond them as an independent and abstract unity. The Absolute is a 'complex unity', and not a mere aggregate, of finite individuals, and it invests them with a new significance by encompassing them (Haldar 1918: 377). While finite minds seek the Absolute that they are in potentia, the Absolute urges them on to their perfection, through ever-deepening bonds of interrelationality and mutuality. This Absolute is the universal Spirit which is manifested in, and is the ground of, the community of human beings (Haldar 1936: 330-331). However, as we have seen, Mukerji rejected the Hegelian equivalence between reality and rationality and argued that reason should be seen as subordinate to intuition, for reasoning applies only to empirical ways of knowledge, while ultimate reality is apprehended only through intuitive experience (Mukerji 1928: 428). The pure being of Advaita is not a bare abstraction, as Hegelians claim, for while it is 'equal to nothing from the standpoint of conceptual thought' it can also be 'the content of an intuitional experience' (Mukerji 1928: 411). Shrivastava develops this critique of Hegelianism in his study of Bradley and Śamkara-while they both speak of ultimate reality as an immediate experience which is beyond all relations, they disagree over the possibility of attaining such an experience. For Samkara, the Absolute is not completely inaccessible, since it is present as the true self in everyday experiences, whereas for Bradley it is a 'mere focus imaginarius' which is conceivable but not actually attainable (SB, 36). Bradley's view is, in fact, representative of the 
agnosticism that Western philosophy culminates into, since it relies solely on reason without the supplementation of an intuitive vision of reality. Bradley arrives at his Absolute through speculative reasoning, and his Absolute is at best an idea of reason in the Kantian sense and not an indubitable fact of everyday experience (SB, 40).

In other words, while Hegelian absolutisms provided the common philosophical vocabularies with which one could speak of the Absolute of Advaita, a fundamental assumption of these absolutisms had to be rejected, namely, the view that the deep structures of reality were amenable to discursive reasoning. For instance, N.G. Damle argues for an 'integral idealism' which rejects any 'abstract or exclusive form of monism, whether materialistic or spiritualistic ...' Damle rejects the subjectivist view that one can 'destroy the world by going to sleep', such that one can dissolve into an impersonal Absolute which consumes everything, and also a spiritual pluralism which views the world as composed of metaphysically real finite selves alongside the Absolute. However, the Absolute, which is a 'concrete, spiritual whole in which all differences are reconciled', can be apprehended not through conceptual means but through an intuition in which the duality between the subject and the object is dissolved (Damle 1936: 188-189). He presents his idealism in these terms: 'According to our theory, reason criticizes itself, and recognizing its own limitations it points beyond itself to intuition. It implies disagreement with the view that identifies Thought and Being, Real and Rational, and thus is opposed to Pan-logism' (Damle 1936: 192).

\section{Conclusion}

Our study has highlighted some distinctive ways in which Advaitic themes were reconfigured by Mukerji, Raju, Shrivastava, and others, through a critical interrogation of a variety of Hegelian idealisms. Given the declining fortunes of Hegel in many Anglophone philosophical circles during the second half of the last century, these figures are rarely studied today because of their association with Hegelian idioms. However, several reassessments of post-Kantian idealisms have pointed to the continuing significance of Hegelian themes in both the 'analytic' and the 'continental' traditions (Dunham, Grant, and Watson 2011). The term 'idealism' itself, it is pointed out, is not equivalent to some form of Berkeleyeanism, for the trajectories of post-Kantian thought, involving figures such as Fichte, Schelling, and Hegel, were shaped by a wide range of idealisms such as material idealism, empirical idealism, critical idealism, transcendental idealism, and absolute idealism (Altman 2014: 4). The precise characterization of Hegel's 'idealism' too has been an intensely debated topic in Hegel scholarship, with some interpreters arguing that it is a misreading of Hegel to understand him as propounding a metaphysicalreligious view in which reality is constituted of Spirit which is actualized in the world (Wartenberg 1993: 102-129). In the light of these recent evaluations, we can view the philosophers we have discussed as engaged in diverse modes of interrogating and appropriating elements of post-Kantian idealisms mediated through Green, Caird, and Bradley. By positioning Śamkara vis-a-vis Hegelianisms, they became participants in contemporary Indo-European philosophical 
conversations and added a significant chapter to the ongoing receptions of the ‘idealism' of Śamkara in modern Advaita.

Open Access This article is distributed under the terms of the Creative Commons Attribution 4.0 International License (http://creativecommons.org/licenses/by/4.0/), which permits unrestricted use, distribution, and reproduction in any medium, provided you give appropriate credit to the original author(s) and the source, provide a link to the Creative Commons license, and indicate if changes were made.

\section{References}

Altman, M. C. (2014). Introduction: What is German idealism? In M. C. Altman (Ed.), The Palgrave handbook of German idealism (pp. 1-11). London: Palgrave Macmillan.

Bhushan, N., \& Garfield, J. L. (2011). The Plato of Allahabad: A.C. Mukerji's contributions to Indian and to world philosophy. In N. Bhushan \& J. L. Garfield (Eds.), Indian philosophy in English: From renaissance to independence (pp. 455-469). Oxford: Oxford University Press.

Biswas, T. (2015). The notion of absolute: Hegel and Hiralal Haldar. In S. Deshpande (Ed.), Philosophy in Colonial India (pp. 103-118). New Delhi: Springer.

Boucher, D., \& Vincent, A. (2012). British idealism: A guide for the perplexed. London: Continuum.

Bradley, F. H. (1893). Appearance and reality. London: Swan Sonnenschein \& Co.

Caird, E. (1889). The critical philosophy of Immanuel Kant (Vol. I). Glasgow: James Maclehose \& Sons.

Caird, E. (2002) [1883]. Hegel. London: Cambridge Scholars Press Ltd.

Damle, N. G. (1936). The faith of an idealist. In S. Radhakrishnan \& J. R. Muirhead (Eds.), Contemporary Indian philosophy (pp. 177-194). London: George Allen \& Unwin Ltd.

Deshpande, S. (2015). Introduction-modern Indian philosophy: From Colonialism to Cosmopolitanism. In S. Deshpande (Ed.), Philosophy in Colonial India (pp. 1-39). New Delhi: Springer.

Dudley, W. (2007). Understanding German idealism. London: Acumen.

Dunham, J., Grant, I. H., \& Watson, S. (2011). Idealism: The history of a philosophy. London: Acumen. Halbfass, W. (1990). India and Europe: An essay in philosophical understanding. Delhi: Motilal Banarsidas.

Haldar, H. (1896). Some aspects of Hegel's philosophy. The Philosophical Review, 5, 263-277.

Haldar, H. (1917). Leibniz and German idealism. The Philosophical Review, 26, 378-394.

Haldar, H. (1918). The absolute and the finite self. The Philosophical Review, 27, 374-391.

Haldar, H. (1936). Realistic idealism. In S. Radhakrishnan \& J. R. Muirhead (Eds.), Contemporary Indian philosophy (pp. 315-331). London: George Allen \& Unwin Ltd.

Mukerji, A. C. (1928). Some aspects of the absolutism of Shankaracharya (a comparison between Shankara and Hegel). Allahabad University Studies, 4, 375-429.

Mukerji, A. C. (1936). Suggestions for an idealistic theory of knowledge'. In S. Radhakrishnan \& J. R. Muirhead (Eds.), Contemporary Indian philosophy (pp. 433-453). London: George Allen \& Unwin Ltd.

Mukerji, A. C. (1943). The nature of self. Allahabad: Indian Press.

Mukerji, A. C. (2011). The realist's conception of idealism. In N. Bhushan \& J. L. Garfield (Eds.), Indian philosophy in English: From renaissance to independence (pp. 473-498). Oxford: Oxford University Press.

Nettleship, R. L. (Ed.). (1888). Works (Vol. 3). London: Longmans and Green.

Norman, R. (1976). Hegel's phenomenology: A philosophical introduction. London: Sussex University Press.

Raju, P. T. (1937). Thought and reality: Hegelianism and Advaita. London: G. Allen \& Unwin Ltd.

Shrivastava, S. N. L. (1968). Śamkara and Bradley: A comparative and critical study. Delhi: Motilal Banarsidass.

Sinnerbrink, R. (2007). Understanding Hegelianism. London: Acumen.

Wartenberg, T. E. (1993). Hegel's idealism: The logic of conceptuality. In F. C. Beiser (Ed.), The Cambridge companion to Hegel (pp. 102-129). Cambridge: Cambridge University Press. 